\title{
Musings on a Pleasant Disease: A Nonmedical Report
}

J OHN MARTIN, M.D.

Use three Physicians still; first Doctor Quiet, Next Doctor Merryman, and Doctor Dyet. ${ }^{1}$

It is not just an old adage that "some persons enjoy their illness." It can be a pleasant fact.

Christmas in our home in a small Illinois town on the banks of the Mississippi had the excitements that most of us remember from our childhood. I remember one of my earliest gifts, an eight or ten page linen book, in colors, with pictures of strange looking people. I did not understand that book: a little boy whipping old men in front of a temple; a tall, fair-haired man riding a donkey; the same man later nailed to a cross, with a background of weeping women, soldiers, and naked babies with wings flying about in dark clouds. It was pretty, but the story didn't register with me at the age of four or five. I liked better the cardboard-backed color book with A for red apple, D for dog, J for Jack, $M$ for man, and so on.

Not long afterwards I was enjoying Mrs. Wiggs of the Cabbage Patch, The Five Little Peppers and How They Grew, and Jessica's First Prayer. Later I switched my interests to the Tom Swift series, the doings of Horatio Alger's heroes, and the adventures of Henty's characters in India. Still later, The Winning of Barbara Worth, The Virginian, Tarkington's Penrod series, Black Beauty, and endless Zane Grey stories were grist for my mill. Access to these books invariably came through their arrival as a Christmas gift, either to me or to a brother or sister, for each child in our family always received a book for Christmas.

1 From Regimen sanitatis salernitarum, ca 1100. First printed in 1484, the quotation here is from the 1608 English translation by Sir John Harrington, inventor of the water closet. 
Later, in high school and college, I was fortunate enough to have teachers who actually made literature fun and not a chore. Anna Drummond, my college teacher of English and American literature for two years, had large classes in a small college. Because she could make Shakespeare's comedies funny, could make even calloused youth understand the agony of King Lear, and could dispel the mystery as well as the boredom of much of the required poetry, I began to feel hooked on "just reading." I always bought and kept a book if I could afford it. As I look back at that time I see that most of the books were serious, genuinely good books (Dickens, Thackeray, Hawthorne, Poe, Hardy, Conrad), but not all. There were some risqué bits as well, such as DeMaupassant's short stories, in French, and Rabelais's Tales. (Compare the recent The Hite Report, Fear of Flying, Looking for Mr. Goodbar, Hustler Magazine.)

During the years of medical school and postgraduate training, I bought and kept all text books, and continued to acquire a modest collection of general literature in English, French, and German. (The only book I ever wantonly destroyed was my high school algebra text. I threw it into a snowdrift on the corner of Elizabeth Street and Columbia Terrace, Peoria, Illinois, on the last day of the course!) An elective course in medical history for two hours every Saturday morning in the fourth-floor assembly room of Northwestern University Medical School was the real beginning of my present disease. The room was always packed with both students and faculty listening to the fascinating lectures by Dean Irving S. Cutter or Professor of Anatomy Barry J. Anson, and watching old style $4 \times 4$ glass slides of pictures taken from books on the history of medicine. But here a sad observation: courses, or even sporadic lectures on the history of medicine, seem rarely to be given nowadays in medical school. Is this a lack of informed or interested lecturers? of interested students? of lack of time because of the pressures of a crowded curriculum? of a change in emphasis in some aspects of education? No matter what the reason, it is a loss to modern medical students. It is a taste of a fine flavor which they will never know.

Visits to Northwestern University's modest collection of rare old medical books, studying the displays of old books in the corridor of the Anatomy Department on the seventh floor, browsing wishfully through the stacked tables and shelves of Marshall Field and Company and Kroch's-Brentano's, I began to sense an increase of symptoms of a vaguely realized "problem" which had "bothered" me for some time. I didn't actually suffer; it was more of an inward itch. I finally recognized the disease as BIBLIOMANIA, a word indeed de- 
fined in medical dictionaries. The disease has persisted and grown worse, though repeated self-administered treatments offer only temporary relief of symptoms. I finally realized that my bibliomania was complicated by "collector's fever," a happy combination. It is incurable.

The years of training and early surgical practice left little time or money for the collecting of old medical books. But if funds had been available, then was the time to buy and collect. The prices of desirable items were then but a fraction of what they are now and have been for the past decade or two. Prices have skyrocketed to ten, twenty, even thirty times what they were twenty years ago.

Seven months spent in Rome during the war, in 1944, were a privilege. One day while wandering about the Piazza Bernini, watching the water pour over Bernini's Fountain of the Triton, I found a dark little basement shop, almost bereft of stock, and there I discovered one of my first purchases of books now in the Rare Book Room in the Health Sciences Library: Sydenham's Opera Medica (1735). And at the top of the Spanish Stairs, at 23 Via Sistina, I found the delightful Mr. C. E. Rappaport, English but a long-time resident of Rome, who dealt in a select collection of old books, manuscripts, and prints. It was from him, later in 1949, that I purchased the first edition of Vesalius's Fabrica (1543) for the outrageous price of $\$ 740$. Two years ago a copy of the same book sold in this country for $\$ 25,000$.

Though my principal interests were and still are, so far as collecting is concerned, rare old medical books, my interests are actually catholic. I continue to add to my library first editions of biographies, travel, and general literature (especially 18th- and 19th-century works in French and English), as well as fine bindings, some fore-edge paintings, and the beautifully designed and printed classics of the Limited Editions Club. Of my library, those books not now in the Rare Book Room at the Health Sciences Library or in the Special Collections Department of the Main Library at The University of Iowa, eventually will be deposited there.

Through the suggestions and help of Dr. Robert C. Hardin, Dr. William B. Bean, and especially Dr. Leslie W. Dunlap, dean of Library Administration, the selection of The University of Iowa was made my logical choice for the final disposition of my library. The realization that the books are now in a safe and proper place, where they can be used and enjoyed, is a source of great satisfaction, and more than makes up for the wave of sadness I admit feeling when I now look at my mostly empty shelves. On occasion I have been asked, even by Iowans, "But how did you ever decide to give them to Iowa? Why not 
Harvard, or the Huntington Library, or . . . ?" My patient answer has finally become, simply, "Why NOT Iowa?"

The joys of living with a condition of bibliomania are many and varied. Each dealer's catalogue, so often beautifully designed and illustrated, brings on the old symptoms of excitement and restlessness allayed only by outright purchase of a wanted book. Waiting for delivery, opening the delivered package, the first skim through the historic pages, are very special times of satisfaction. Many times the books have been obtained directly from a dealer by way of a telephone conversation or a letter, without the books ever having been advertised or placed in a catalogue. It is well to let a favorite dealer know one's wants, thus avoiding the risk of having a special book sold quickly when being made publicly available. Most dealers are well informed on medical history. From them I have learned much, and among them I have made some good friends. I have found them to be uniformly honest and reliable. Their catalogues, discounting occasional bits of hard-sell hyperbole, represent much expenditure of time and money in research and printing.

The history of medicine teaches us, if we will only take a somewhat comprehensive survey of it, that at all times permanent advances have been marked by anatomical innovations, and that every more important epoch has been ushered in by a series of important discoveries concerning the structure of the body. ${ }^{2}$

Anatomical works, and especially anatomical atlases, have a special attraction, and, incidentally, they are usually the more expensive books. The Rare Book Room at Iowa is strong in such acquisitions. Many of them are examples of rare beauty in the art of printing and illustration. For the bibliomaniac to open and fondly leaf through one of these treasures, sensing the beauty of its physical self and its spiritual and intellectual importance in the long history of science, is reward enough for the self-denials he may have made in order to own the book.

Just as the quality of art expressed in the design and printing of the Gutenberg Bible has remained time tested to awe the beholder even today, just so do scores of early medical works express the combination of art and science. What is richer than the hand-illuminated initials of Pietro d'Abano's Conciliator (1476)? What of the magnificent plates with pictorial backgrounds, such as in Vesalius's and Albinus's works? They are more than mere anatomical illustrations. What

2 Rudolph Virchow, Cellular-Pathologie (Berlin, 1858), chapter I. 
of Scarpa, John Hunter, Caldani, and the exquisite colored plates of Leonhart Fuchs, Charles Bell, Lizars, Cruveillier? Indeed, colored printing is no recent thing; well over 450 years ago many author portraits and title pages were printed in two, sometimes three colors. It was the rare gift of early book makers to invest their works not only with arresting design and illustrations, but also with a quality of materials (paper made of pure linen; nonacid inks) which have lasted for centuries. But again, just as many in the world of medical science do not appreciate the importance of medical history, just so do most museums of art seem to be unaware of the mine of artistry to be found in rare old medical books.

Collecting these books has brought not only an understanding of the steady onward development of the science of medicine, but it has, as well, shown the intermeshing and interdependence of scientific progress with the cultural, social, political, and religious history from four to five centuries before Christ, from the shadows of Hippocratic thought to the technical intricacies of the space age. These previous records compel an appreciation of our forebears, of their struggles, failures, and successes. They impose a proper humility, that we may be thankful to those giants of the past.

Many examples in medical history relate directly to this. Paracelsus, tormented, misunderstood, deemed a crazy charlatan by most contemporaries, wrote the first work on the occupational diseases of miners and metallurgical workers, Von der Bergsucht oder Bergkranckheiten drey Bucher (1567), though more than four hundred years have passed and the miner's lot is still far from a happy one. What might have been the course of events had not Henry VIII of England and Ivan the Terrible of Russia had one thing in common: syphilis? (It is altogether unlikely that, as one tale has it, Henry acquired his disease by Cardinal Wolsey's whispering in his ear!) Pope Alexander VI, progenitor of the historically impressive Borgia family, was syphilitic; Henry III and Louis XIV of France had syphilis; Vesalius strongly implied that his royal patron and patient, Emperor Charles V, was infected. Nietzsche, Schubert, Beethoven, Benvenuto Cellini, and many others equally famous were tainted by this disease which has such devastating effects on the brain in its late stages. What might have been the human condition had it not been for Frascatorius and his early understanding of the basics of contagious diseases, especially syphilis? Who can underestimate the saving from human misery given us by the epochal works of Ricord, ${ }^{3}$ Hunter, Jenner, Ehrlich and Hata,

3 Philippe Ricord was one of the most famous venerologists in medical history. It was he who corrected Hunter's erroneous idea of the identity of gonorrhea and syphilis. His professional experiences apparently led him to be pessimistic as to the 
Wassermann, Virchow, Schaudinn, and the twentieth-century Flemming? What more might we have early learned of the physiology of the cardiovascular system had not the library and papers of the reticent Royalist, William Harvey, been burned by Cromwell's mobs? Daniel Defoe was a satirist and social critic, not a physician, but he wrote a clinically accurate "eyewitness" account of the great plague of London in 1665, though he was at that date only six years old. Boccaccio in the Decameron (1353) gave an accurate account of the social effects of the plague in Italy. Walter Reed and William Gorgas and their work with dysentery, malaria, and yellow fever in the effort to build the Panama Canal; David Livingstone and his discovery and description of the tsetse fly in the course of his missionary travels: these are illustrations of the close relationship of the development of medicine and the course of human events.

One day a friend, a very strict Fundamentalist minister, wondered how I could ever have enjoyed the company of the Arabs, as I did, while I was in Algeria during World War II. Infidels, pagans, they knew nothing of Christ, had contributed nothing to the world but trouble, were a blot on the world scene. Thus did ignorance reveal itself. It would have been useless to tell him of Mesuë, Rhazes, Avicenna, Abulcasis, Avenzoar, Averroes, and many others. I did not try to explain to him that, among other accomplishments of the Moslem world for which we should be grateful, was the fact that Greek and Roman medical thought, as well as what little progress there was in the Middle Ages, would have been lost had the Christian Church with its intellectual shackles had its way, and had not the Arab scholartranslators (mainly copiers and compilers, that is true) preserved these priceless early works. The Arabic influence in the progress of medicine should never be underrated.

Each new acquisition brings temporary, but only temporary, relief. The recent arrival of Tagliacozzi: De curtorum chirurgia (1597) was a great lift. But now if I could only find a copy of Achillini, Annotationes anatomicae (1520), and a Dryander, Anatomia capitis (1536), and a Withering, An Account of the Foxglove and Some of its Medical Uses (1785), and a Fothergill, On a Painful Affliction of the Face (1776), and ....4

morality of human beings. Oliver Wendell Holmes said he was "the Voltaire of pelvic literature,-a skeptic as to the morality of the race in general, who would have submitted Diana to treatment with his mineral specifics, and ordered a course of blue pills [mercury] for the vestal virgins." Holmes, Medical Essays (Boston: Houghton, Mifflin and Co., 1892), p. 437.

4 Books and authors referred to in this article may be found in the Rare Book Room of the Health Sciences Library. 


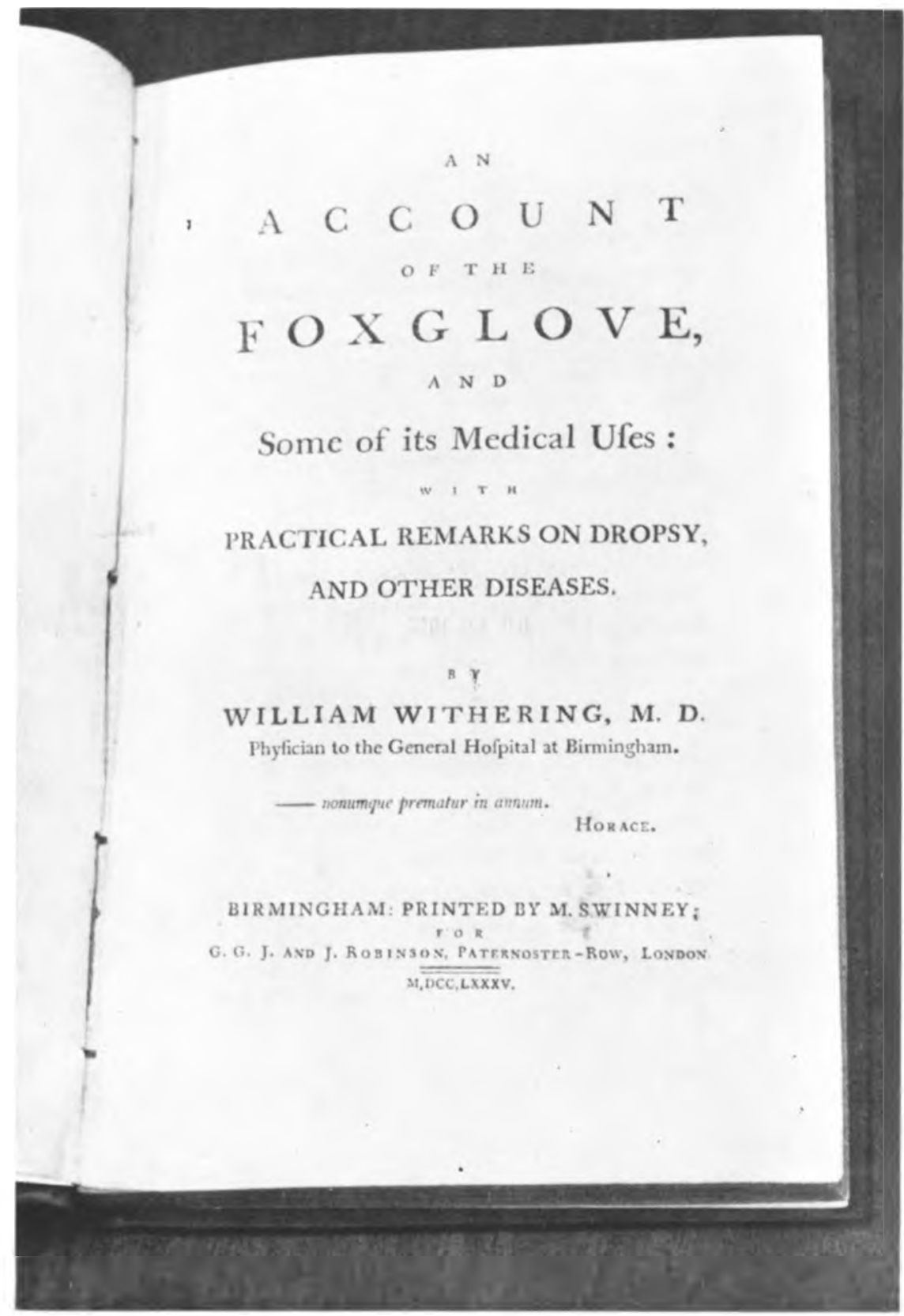

Title page of a rare volume recently added to the History of Medicine Collection. ('niversity of Iowa Libraries. This copy of Withering's An Account of the Foxgloee and Some of its Medical Uses (1785) is a gift of John Martin, M.I).

$[27]$ 


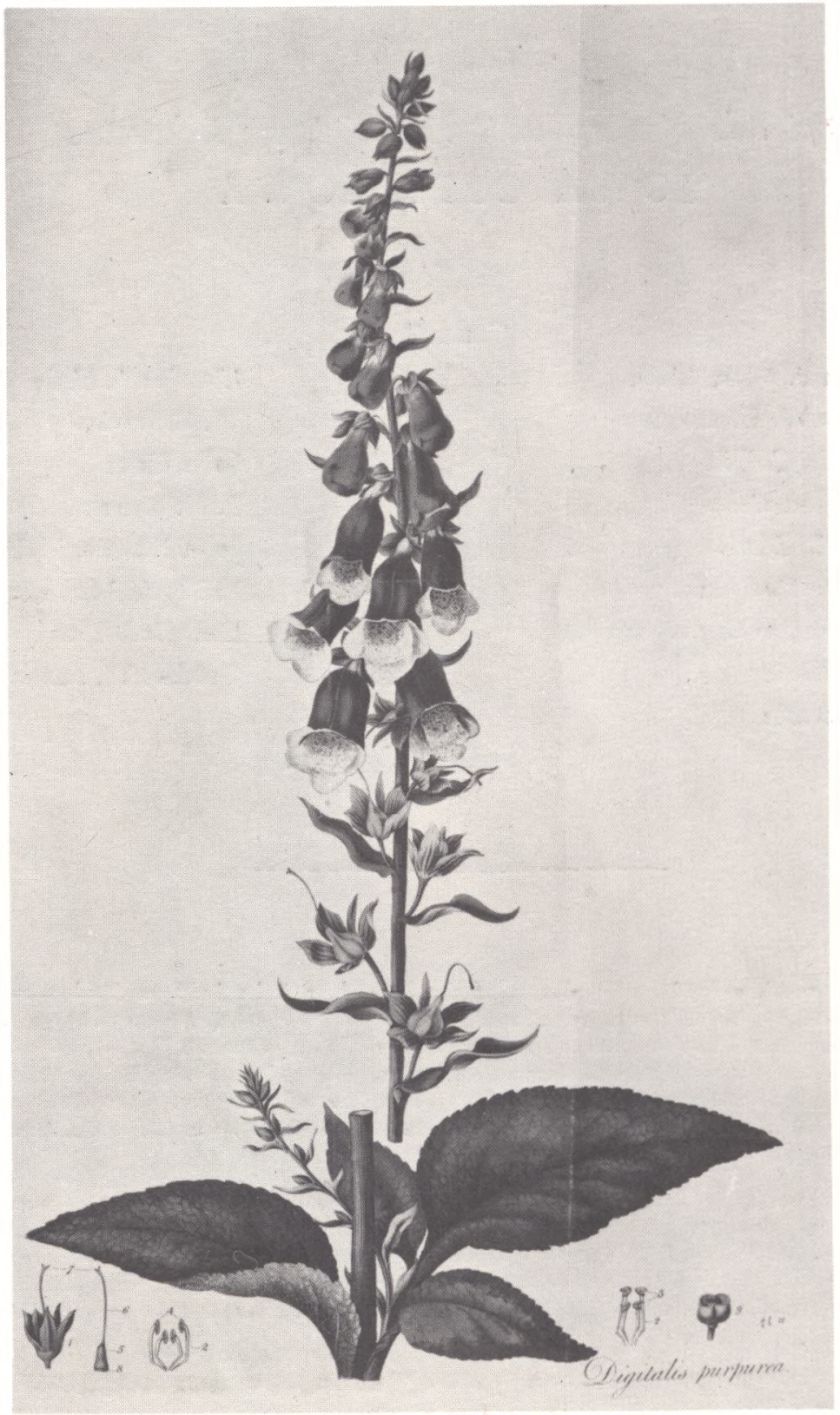

http://ir.uiowa.edu/bai/vol28/iss1 